\title{
Odnos med vzgojnimi stili, vpletenostjo staršev in šolsko uspešnostjo mladih v Sloveniji
}

Tina Cupar, Danijela Lahe, Andrej Kirbiš

\section{Uvod}

ک̌

Solska uspešnost mladostnikov predstavlja enega izmed pomembnih kazalnikov njihovih pozitivnih razvojnih izidov. V skladu s pogosto uporabljenim pristopom $\mathrm{k}$ preučevanju razvojnih izidov, tj. Bronfenbrennerjevo ekološko teorijo človekovega razvoja (1979), je tudi šolska uspešnost odvisna od številnih kontekstualnih dejavnikov okolja. Ti zajemajo različne okoljske ravni (npr. raven posameznikove družine in prijateljev, ravni institucij in tudi ravni širšega sociokulturnega konteksta), ki v medsebojni interakciji na različne načine prispevajo $\mathrm{k}$ posameznim izidom. Za šolsko uspešnost mladostnikov tako poleg individualnih značilnosti učencev (bioloških, kot so npr. spol, inteligentnost in genetske predispozicije) pomembno vlogo igrajo številni dejavniki neposrednega okolja, v katerem mladostnik odrašča. To so predvsem značilnosti neposrednega družinskega okolja (Fan in Chen, 2001; Marjanovič Umek, 2006a), šolskega okolja (npr. odnosa z vrstniki in učitelji; OECD, 2012), pa tudi širših značilnosti družbenega in kulturnega okolja (npr. pomena izobraževalnih dosežkov v družbi, gl. npr. Chao, 1994).

Predvsem družinsko okolje je tisto, ki postavlja pomembne temelje za posameznikov nadaljnji razvoj. Značilnosti družine, v kateri posameznik odrašča, predvsem pa starši in njihov odnos $z$ mladostniki, predstavljajo različne vidike družinskega okolja, ki vplivajo na izobraževalne izide mla- 
dostnikov. Pretekle raziskave tako kažejo, da je poleg nekaterih sociodemografskih dejavnikov (npr. socioekonomski položaj staršev oz. izobrazba staršev, bivalno okolje, struktura družine itd.; gl. npr. OECD, 2012) zlasti pomembna vzgoja oz. vzgojni stili staršev (Masud et al., 2015; Pong et al., 2010), pa tudi vpletenost staršev v šolsko delo otrok in mladostnikov (Boonk et al., 2018; Pinquart, 2016). Kljub raziskani vlogi vzgojnih stilov staršev in vpletenosti staršev $\mathrm{v}$ posameznih raziskavah pa so redkejše raziskave, ki preučujejo vlogo obeh vidikov sočasno (gl. npr. Steinberg et al., 1992; Taylor et al., 1995).

Namen pričujoče raziskave je bil podrobneje preučiti vlogo družinskih dejavnikov pri šolski uspešnosti mladih v Sloveniji, zlasti vlogo staršev in njihovih vedenj. Naša cilja sta bila preučiti: (1) pomen vsakega posameznega starševskega kazalnika (tj. vzgojnih stilov in vpletenosti staršev v izobraževanje) za šolsko uspešnost mladih in (2) učinke različnih družinskih dejavnikov (tako sociodemografskih in socioekonomskih značilnosti kot tudi obeh starševskih kazalnikov) na šolsko uspešnost mladih, kadar so analizirani hkrati v multivariatnem modelu.

\section{Teoretski okvir}

\section{Vloga staršev pri šolski uspešnosti mladih}

Številne pretekle raziskave kažejo, da lahko vedenja staršev pomembno prispevajo k izobraževanim izidom oz. šolski uspešnosti mladih (Masud et al., 2015; Pinquart, 2016). Pri tem ima ključno vlogo starševska vzgoja oz. vzgojni stili. Ti predstavljajo skupek stališč in vedenj staršev, ki se nanašajo na vzgojo otrok (Darling in Steinberg, 1993), ki se glede na stopnjo izraženosti dveh dimenzij (starševske odzivnosti oz. topline in nadzora oz. zahtevnosti) preučujejo $\mathrm{v}$ okviru klasične tipologije treh vzgojnih stilov (avtoritarnega, avtoritativnega in permisivnega; Baumrind, 1970; Baumrid et al., 2010) ali štirih vzgojnih stilov (omenjenih treh in izključujočega vzgojnega stila; Maccoby in Martin, 1983; gl. tudi Garcia et al., 2019).

Starši z uporabo različnih vzgojnih stilov postavljajo pomembne temelje za mladostnikov razvoj kompetenc in vedenj (Baumrind et al., 2010; Steinberg et al., 1989), kar se nadalje lahko odraža tudi na različnih področjih izobraževalnih izidov, kot so angažiranost za šolsko delo in spopadanje s šolskimi zadolžitvami (Aunola et al., 2000; Steinberg et al., 1992; Strage in Swanson Brandt, 1999), predvsem pa vpliva na šolski uspeh (gl. npr. Dornbusch et al., 1987; Newman et al., 2015; Pinquart in Kauser, 2018). Raziskave 
tako npr. kažejo, da je avtoritativni vzgojni stil (visoka odzivnost in visok nadzor) praviloma povezan $\mathrm{z}$ višjo šolsko uspešnostjo, avtoritarni (nizka odzivnost in visok nadzor) in izključujoči (nizka odzivnost in nizek nadzor) pa z nižjo (Abar et al., 2009; Majumder, 2016; Yasmin et al., 2014). Najbolj neenotno se $\mathrm{v}$ različnih raziskavah kaže predvsem vloga permisivnega vzgojnega stila - čeprav po eni strani nekatere raziskave kažejo njegovo povezanost $s$ slabšo šolsko uspešnostjo kot pri avtoritativnem (Masud et al., 2015), pa po drugi strani vse več novejših raziskav kaže, da je lahko povezan tudi z boljšo šolsko uspešnostjo in šolskimi izidi (Calafat et al., 2014; Garcia et al., 2019).

Nekateri avtorji ob tem izpostavljajo, da je eden glavnih mehanizmov, zaradi katerega toplina/bližina staršev - bodisi v kombinaciji brez nadzora (permisivni vzgojni stil) ali z nadzorom (avtoritativni vzgojni stil) - veča šolsko uspešnost, spodbujanje večje psihosocialne zrelosti, s čimer je povezana večja samozavest in motiviranost za delo (Calafat et al., 2014; Steinberg, 2001). Po drugi strani pa avtoritarni in zanemarjajoči stil znižujeta šolske izide bodisi zaradi pretiranega nadzora/zlorabe moči (avtoritarni vzgojni stil; gl. npr. Baumrind et al., 2010: 185) ali popolne starševske odsotnosti (zanemarjajoči vzgojni stil), ki na otroka deluje destimulativno.

Kljub prepoznani pomembni vlogi vzgojnih stilov pri šolskih izidih otrok pa raziskovalci izpostavljajo tudi velik pomen vedenj staršev, ki se konkretneje navezujejo na izobraževanje, kot je npr. "starševska vpletenost« (angl. parental involvement) v šolanje in izobraževalni proces otroka. Starševska vpletenost zajema različne vidike angažmaja staršev, in sicer tako njihovega sodelovanja s šolo in učitelji kot tudi vključevanja v izobraževanje otrok v okviru družine. Še posebej je pomembna v Sloveniji, saj podatki mednarodne raziskave sedmih evropskih držav o vpletenosti staršev v izobraževanje otrok kažejo, da so prav v Sloveniji starši najpogosteje vpleteni v izobraževanje svojih otrok (Ule, 2015). Ob tem je pomembno izpostaviti, da nekateri vidiki vpletenosti staršev bolj prispevajo $k$ uspešnosti kot drugi. Tako je denimo komunikacija staršev $\mathrm{z}$ otroki o šolskih aktivnostih $\mathrm{v}$ večji meri povezana s šolskimi izidi kot pa nadzor staršev nad šolskimi aktivnostmi in domačimi nalogami (Castro et al., 2015), ki je s šolsko uspešnostjo lahko tudi negativno povezana (Hill in Tyson, 2009).

Glede na številne oblike vpletenosti staršev v mladostnikovo izobraževanje se vpletenost staršev $\mathrm{v}$ šolo med drugim preučuje $\mathrm{v}$ okviru dveh dimenzij. Prva je podpora staršev, ki se nanaša na spodbujanje otroka in nudenje pomoči, ko jo ta potrebuje, in se je v preteklih raziskavah izkazala za 
ključni dejavnik otrokovih izobraževalnih izidov (Anderson et al., 2003; Hoferichter in Raufelder, 2019; Raufelder et al., 2015;). Po drugi strani pa starši pogosto, $\mathrm{v}$ želji pomagati svojemu otroku, do svojih otrok izražajo stališča in privzemajo vedenjske vzorce, ki jih njihovi otroci doživljajo kot pritisk, torej kot nerealna oz. (pre)visoka pričakovanja, cilje in zahteve do otroka in njegovega šolskega angažmaja in dosežkov (Anderson et al., 2003; Leff in Hoyle, 1995; Raufelder et al., 2015). Ob tem lahko starševski pritisk mladostniki doživljajo ne glede na lastno šolsko uspešnost. Po eni strani lahko pritisk doživljajo v šoli manj uspešni otroci (kadar starši vztrajajo, da mladostniki izboljšajo svoj uspeh), po drugi pa tudi nadpovprečno uspešni otroci (denimo zaradi starševskega pritiska glede ohranitve visokih ocen). Nekatere raziskave denimo kažejo, da največ pritiska staršev doživljajo povprečno uspešni učenci (Deb et al. 2015), druge pa, da je pritisk/nadzor staršev povezan s slabšim šolskim uspehom in izidi, starševska podpora pa z višjimi (Hoferichter in Raufelder, 2019; Karbach et al., 2013; Núñez et al., 2019). Obe dimenziji starševske vpletenosti v izobraževanje mladostnika torej igrata pomembno vlogo, a pogosto $\mathrm{z}$ različnimi izidi mladostnika (Amado et al. 2015; Anderson et al. 2003; Ringeisen in Raufelder 2015).

Poleg staršev k šolski uspešnosti mladostnikov pomembno prispevajo tudi druge značilnosti neposrednega družinskega okolja. Številne raziskave denimo kažejo, da je pomemben dejavnik šolske uspešnosti mladih socioekonomski status družine, pri čemer so mladostniki iz družin z višjim socioekonomskim statusom $\mathrm{v}$ šoli bolj uspešni kot tisti iz družin $\mathrm{z}$ manj izobraženimi starši ali z nižjim ekonomskim položajem (Flere et al., 2009; OECD, 2012; Peček et al., 2006). Prav tako nekatere raziskave izpostavljajo pomembno vlogo strukture družine (Jeynes, 2005; Rodgers in Rose, 2001), pri čemer imajo predvsem otroci ločenih staršev pogosteje slabši šolski uspeh kot otroci iz tradicionalnih družin (Amato, 2001; Gorard in Smith, 2004).

\section{Raziskovanje vloge družinskega okolja pri šolski uspešnosti v Sloveniji}

Tudi v Sloveniji posamezne pretekle raziskave izpostavljajo prispevek različnih vidikov družinskega okolja mladostnikov $\mathrm{k}$ njihovim šolskim izidom, zlasti vloge staršev. Tako npr. raziskave na vzorcih slovenske mladine kažejo, da so boljši šolski izidi povezani $\mathrm{z}$ avtoritativnim vzgojnim stilom (Cupar, 2018; Flere in Tavčar Krajnc, 2011; Kirbiš, Cupar in Tavčar Krajnc, 2021) oziroma slabši izidi $z$ avtoritarnim in permisivnim vzgojnim stilom 
(Cupar, 2018; Cupar in Lahe, 2019; Flere in Tavčar Krajnc, 2011). Po drugi strani pa je npr. mednarodna raziskava, ki je poleg Slovenije vključevala tudi pet drugih evropskih držav, podala nekoliko drugačne ugotovitve. Tako kot v nekaterih drugih državah se je tudi v Sloveniji namreč izkazalo, da je avtoritativna vzgoja sicer pozitivno povezana s šolskimi izidi, a so permisivno vzgojeni mladostniki iz Slovenije dosegali celo boljšo šolsko uspešnost kot avtoritativno vzgojeni (Calafat et al., 2014). Raziskava, ki se je osredotočila na nekatere druge vidike starševske vloge, pa je na vzorcu 427 mladostnikov iz Slovenije npr. ugotovila, da so boljši šolski izidi povezani z manjšim starševskim pritiskom in pomočjo pri delu $\mathrm{v}$ šoli ter $\mathrm{z}$ nadzorom in organizacijo časa za učenje (Marjanovič Umek et al., 2006: 45).

Med drugimi dejavniki družinskega okolja se je v slovenskih raziskavah kot pomemben izkazal tudi socioekonomski status družine, pri čemer se med posameznimi kazalniki kot statistično značilen dejavnik kaže zlasti izobrazba staršev. Številne raziskave v zadnjem desetletju tako potrjujejo, da imajo otroci in mladostniki bolj izobraženih staršev tendenčno višjo šolsko uspešnost (gl. npr. Cupar in Lahe, 2019; Flere, 2009; Flere in Tavčar Krajnc, 2011; Marjanovič Umek et al., 2006; Peček et al., 2006).

\section{Raziskovalna vrzel in namen raziskave}

Navkljub številnim raziskavam šolske uspešnosti otrok in mladostnikov so primerjave učinka vzgojnih stilov in vpletenosti staršev na šolsko uspešnost mladostnikov relativno maloštevilne. Raziskava Steinberga in sodelavcev (1992) na 6.400 ameriških adolescentih je npr. ugotovila pomembno prepletenost vzgojnih stilov in vpletenosti staršev pri šolskem uspehu mladostnikov - učinek starševske vpletenosti na šolski uspeh mladostnikov je namreč večji, če se ta pojavlja v kontekstu avtoritativne vzgoje. Na podlagi meta analize 308 raziskav, $v$ kateri sta bila preučena oba starševska kazalnika (vzgojni stili in vpletenost staršev v izobraževanje), pa je avtor raziskave zaključil, da so »specifična starševska vedenja, usmerjena k spodbujanju šolskega uspeha, " pomembnejša kot (splošnejši) vzgojni stili (Pinquart, 2016: 488). Čeprav pomen prepletenosti različnih družinskih dejavnikov za šolski uspeh mladostnikov nakazujejo tudi nekatere slovenske raziskave (Marjanovič Umek et al., 2006), v Sloveniji in v državah srednje in jugovzhodne Evrope primanjkuje raziskav, ki bi hkrati empirično preučile in primerjale učinek obeh starševskih kazalnikov - vzgojnih stilov in vpletenosti $v$ šolo. Zato je bil namen naše raziskave preučiti odnos med štirimi vzgojnimi stili, starševsko podporo in starševskim pritiskom v času od- 
raščanja (retrospektivno za čas izobraževanja v osnovni šoli) ter sedanjo šolsko uspešnostjo.

\section{Metodologija}

\section{Vzorec}

Analizirali smo podatke vzorca mladih iz Slovenije, starih od 12 do 34 let, ki smo ga s pomočjo spletne ankete pridobili v decembru 2019 in v januarju 2020. Iz celotnega vzorca smo analizirali podvzorec osnovnošolcev, srednješolcev in študentov. V vzorec smo zajeli 1.377 mladih, od tega 248 študentov, 982 dijakov in 147 osnovnošolcev. Povprečna starost je bila 19,25 let $(\mathrm{SD}=2,77)$, v vzorcu je bilo $57,5 \%$ žensk.

\section{Merski instrument}

\section{Odvisna spremenljivka}

Odvisna spremenljivka je bila šolska uspešnost respondenta. Merili smo jo s povprečno šolsko oceno v preteklem šolskem oz. študijskem letu $\mathrm{z}$ vprašanjem: »Kakšna je bila povprečna ocena v preteklem šolskem/študijskem letu?« Respondenti so odgovarjali na 4-stopenjski lestvici (1 - pretežno 1-2/5-6; 2 - pretežno 2-3/7-8; 3 - pretežno 3-4/8-9; 4 - pretežno 4-5/9-10).

\section{Napovedovalne spremenljivke}

Starševski vzgojni stili so bili merjeni z vidika dveh dimenzij, in sicer starševske bližine in starševskega nadzora po vzoru klasičnih tipologij vzgojnih stilov (gl. npr. Baumrind et al., 2010; Maccoby in Martin, 1983). Mladostnike smo spraševali o njihovem odnosu s starši v obdobju zadnjih razredov osnovne šole. Starševska bližina je bila merjena s pomočjo dveh trditev, izbranih iz WAS lestvice (Calafat et al., 2014; Rohner et al., 1978; warmth/ affection scale): "Starši so mi pomagali, kadar sem potreboval/-a njihovo pomoč.«, „Starši so z menoj govorili o načrtih naše družine in se zanimali za moje mnenje.« in s trditvijo »Vsaj z enim staršem sem si bil/-a bližje kakor večina vrstnikov.« (1 - sploh ne drži; 5 - popolnoma drži; Cronbachov alfa = 0,75). Starševski nadzor je bil merjen s tremi trditvami, izbranimi iz PCS lestvice (Calafat et al., 2014; Parental Control Scale; Rohner in Khaleque, 2003; Rohner, 2008), npr. »Starši so določili pravila, ki sem se jih moral/-a držati.« (1 - sploh ne drži; 5 - popolnoma drži; Cronbachov alfa $=0,74)$. 
Skladno s preteklimi raziskavami smo mlade na obeh lestvicah razdelili po mediani po lestvici starševske bližine in starševskega nadzora $v$ dve skupini, nato pa respondente uvrstili v eno izmed štirih skupin vzgojnih stilov: avtoritativnega (visoka bližina in visok nadzor), permisivnega (visoka bližina in nizek nadzor), avtoritarnega (nizka bližina in visok nadzor) in zanemarjajoč (nizka bližina in nizek nadzor).

Starševska podpora pri izobraževanju je bila merjena s tremi trditvami, kjer smo respondente prav tako spraševali o njihovem obdobju obiskovanja osnovne šole. Trditve so bile povzete po različnih preteklih raziskavah, npr. »Kadar sem potreboval/-a pomoč, so moji starši imeli dovolj znanja, da so mi lahko pomagali pri domačih nalogah in drugih šolskih obveznostih." (Pavić, 2016). Vse trditve so bile merjene na lestvici od 1 (sploh ne drži) do 5 (popolnoma drži), Cronbachov alfa $=0,78$. Za namen analize smo odgovore respondentov rekodirali tako, da smo jih razvrstili v tri skupine oz. kvartile glede na stopnjo izraženosti starševske podpore, in sicer: nizko podporo (sploh ne drži in ne drži), srednjo podporo (niti ne drži niti drži) in visoko podporo (drži in popolnoma drži).

Dimenzijo starševskega pritiska pri izobraževanju smo merili s tremi kazalniki, povzetimi po Campbellu (1996), npr.: »Starši niso bili nikoli zadovoljni z mojimi ocenami.« (1 - sploh ne drži zame; 5 - popolnoma drži zame; Cronbachov alfa $=0,53$ ). Za namen analize smo odgovore respondentov rekodirali tako, da smo jih razvrstili v kvartile glede na stopnjo izraženosti starševskega pritiska, in sicer na: nizek pritisk (sploh ne drži in ne drži), srednji pritisk (niti ne drži niti drži) in visok pritisk (drži in popolnoma drži).

\section{Kontrolne spremenlivke}

Prehranska varnost družine je bila merjena $\mathrm{z}$ vprašanjem »Ali ste $\mathrm{v}$ zadnjih 12 mesecih bili vi ali drugi odrasli v vašem gospodinjstvu zaskrbljeni, da vam bo zmanjkalo hrane, preden bo na voljo denar za njen nov nakup?« (1 - nikoli; 4 - vsak mesec ali skoraj vsak mesec). Strukturo družine smo obravnavali v treh kategorijah (1 - reorganizirana družina; 2 - samo mati ali samo oče; 3 - oče in mati). Ekonomski status družine smo merili s samoocenjenim materialnim stanjem respondentove družine: »Kako ocenjujete materialni položaj vaše družine?« (o - visoko podpovprečno, 10 - visoko nadpovprečno). Za izobrazbo matere in očeta so starši za vsakega izmed staršev navedli doseženo stopnjo izobrazbe na lestvici od 1 (osnovna šola ali manj, I. in II. stopnja) do 9 (doktorat znanosti, VIII/2. stopnja). V multiva- 
riatno analizo smo vključili tudi dve sociodemografski spremenljivki: spol (1 - moški, 2 - ženski) in starost mladostnika.

\section{Načrt analize}

Najprej smo izvedli bivariatno analizo in preučili odnose med vzgojnimi stili, podporo, pritiskom in šolsko uspešnostjo. Prav tako smo s primerjavo povprečij in ANOVO preučili razlike $\mathrm{v}$ šolski uspešnosti glede na vse štiri vzgojne stile. Za napovedovanje šolske uspešnosti smo izvedli multivariatno analizo. Zaradi ordinalne odvisne spremenljivke (povprečna ocena) smo uporabili postopek ordinalne regresijske analize. V model smo poleg ključnih napovedovalnih spremenljivk (štirih starševskih vzgojnih stilov, starševske podpore pri izobraževanju in starševskega nadzora pri izobraževanju) vključili tudi zgoraj navedene kontrolne spremenljivke.

\section{Rezultati}

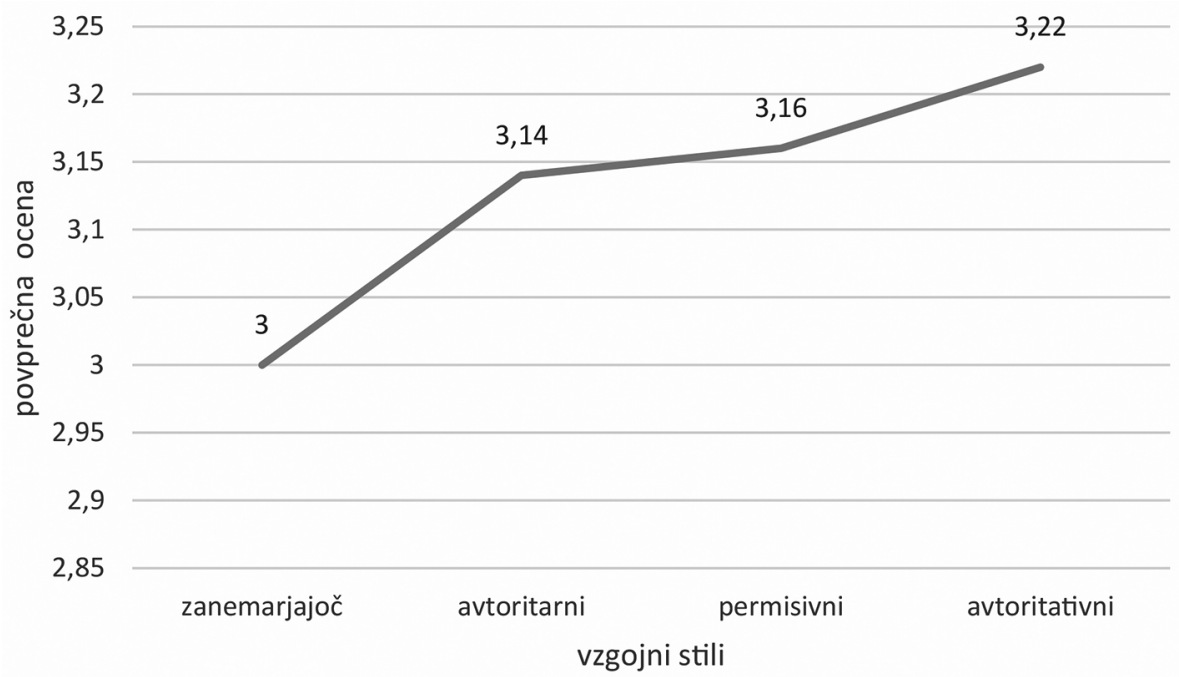

\section{Slika 7: Razlike v povprečni šolski oceni mladih glede na vzgojni stil staršev}

V sliki 7 prikazujemo, kako se šolski uspeh (povprečna ocena) razlikuje glede na vzgojni stil staršev. Glede na to, da je odgovor 3 pomenil »pretežno 3-4/8-9«, odgovor 4 pa »pretežno 4-5/9-10«, lahko sklenemo, da so mladostniki v povprečju dosegali prav dober uspeh. Najvišjo povprečno oceno so dosegali mladi, vzgojeni v avtoritativnem vzgojnem stilu $(\mathrm{M}=3,22, \mathrm{SD}$ 
$=0,76)$, najnižjo pa mladi v zanemarjajočem vzgojnem stilu $(\mathrm{M}=3,00, \mathrm{SD}$ $=0,86)$. Kljub sicer zelo majhnim razlikam med ostalima dvema vzgojnima stiloma so permisivno vzgojeni mladi v našem vzorcu dosegali nekoliko višjo povprečno oceno $(M=3,13, S D=0,79)$ kot avtoritarno vzgojeni ( $M$ $=3,14, \mathrm{SD}=0,84)$. Rezultati ANOVE so pokazali statistično značilne razlike $v$ povprečni oceni med štirimi vzgojnimi stili $(\mathrm{p}<\mathrm{o}, \mathrm{oo1})$.

Tabela 47: Povezanost starševske podpore, starševskega pritiska in šolske uspešnosti mladih

\begin{tabular}{lccc} 
& šolska uspešnost & starševska podpora & starševski pritisk \\
šolska uspešnost & 1 & $0,173^{* *}$ & $-0,073^{* *}$ \\
\hline $\begin{array}{l}\text { starševska podpora pri izobraže- } \\
\text { vanju }\end{array}$ & $0,173^{* *}$ & 1 & $0,098^{* *}$ \\
\hline starševski pritisk pri izobraževanju & $-0,073^{* *}$ & $0,098^{* *}$ & 1
\end{tabular}

Opomba: ${ }^{* *} \mathrm{p}<0,0 \mathrm{I},{ }^{*} \mathrm{p}<0,05$

V Tabeli 47 prikazujemo rezultate bivariatnih korelacijskih analiz med starševsko podporo, starševskim pritiskom in šolsko uspešnostjo mladih. Rezultati so pokazali, da je šolska uspešnost ( $t j$. povprečna ocena $\mathrm{v}$ preteklem šolskem/študijskem letu) statistično značilno pozitivno povezana s starševsko izobraževalno podporo $(\mathrm{r}=0,17 ; \mathrm{p}<0,001)$, s starševskim pritiskom pa negativno $(r=-0,07 ; p<0,01)$. Pri tem je šolska uspešnost močneje povezana s starševsko podporo kot s starševskim pritiskom.

Tabela 48: Ordinalna regresijska analiza dejavnikov šolske uspešnosti mladih

\begin{tabular}{lcccc}
\multicolumn{1}{c}{ Dejavniki } & $\begin{array}{c}\text { Ocena } \\
\text { parametra }\end{array}$ & SE & Wald & p \\
starost & $0,148^{* *}$ & 0,020 & 55,888 & 0,000 \\
\hline spol (1= moški, 2 =̌̌nski) & $0,763^{* *}$ & 0,113 & 45,626 & 0,000 \\
\hline ekonomski status družine & $-0,003$ & 0,034 & 0,006 & 0,940 \\
\hline izobrazba matere & $-0,093^{*}$ & 0,039 & 5,671 & 0,017 \\
\hline izobrazba očeta & $0,08^{*}$ & 0,038 & 4,388 & 0,036 \\
\hline prehranska varnost družine & $0,276^{* *}$ & 0,089 & 9,643 & 0,002 \\
\hline reorganizirana družina & $-0,389$ & 0,217 & 3,205 & 0,073 \\
\hline samo mati ali samo oče & $-0,261$ & 0,217 & 1,446 & 0,229 \\
\hline
\end{tabular}




\section{Dejavniki}

če in mati

zanemarjajoči vzgojni stil

avtoritarni vzgojni stil

permisivni vzgojni stil

avtoritativni vzgojni stil

\begin{tabular}{lcccc}
\hline nizka podpora & $-0,399^{* *}$ & 0,156 & 6,561 & 0,010 \\
\hline srednja podpora & $-0,256$ & 0,135 & 3,599 & 0,058 \\
\hline visoka podpora & 0 & $\cdot$ & $\cdot$ & 0,012 \\
\hline nizek pritisk & $0,34^{*}$ & 0,135 & 6,343 & 0,331 \\
srednji pritisk & 0,128 & 0,131 & 0,946 &. \\
visok pritisk & 0 & $\cdot$ & &.
\end{tabular}

\begin{tabular}{|c|c|c|c|}
\hline $\begin{array}{c}\text { Ocena } \\
\text { parametra }\end{array}$ & SE & Wald & $\mathrm{p}$ \\
\hline
\end{tabular}

o

$\begin{array}{rrrr}-0,046 & 0,159 & 0,089 & 0,772 \\ 0,151 & 0,165 & 0,844 & 0,358\end{array}$

$\begin{array}{llll}0,006 & 0,144 & 0,001 & 0,969\end{array}$

Nagelkerke $\mathrm{R}^{2}=0,136$

Opomba: ${ }^{* *} \mathrm{p}<0,0 \mathrm{I} ;{ }^{*} \mathrm{p}<0,05$.

V Tabeli 48 so prikazani rezultati ordinalne regresijske analize, v kateri je odvisna spremenljivka šolska uspešnost, neodvisne spremenljivke pa oba vidika starševske vloge (vzgojni stili in obe dimenziji vpletenosti staršev v izobraževanje) ter druge sociodemografske in družinske socioekonomske spremenljivke. Napovedovalne spremenljivke so skupaj pojasnile 13,6 \% variance (Pseudo $\mathrm{R}^{2}$ Nagelkerke) v šolski uspešnosti. Izmed vseh v multivariatni model vključenih spremenljivk je bil višji šolski uspeh statistično značilno povezan $\mathrm{z}$ ženskim spolom $(\mathrm{p}<\mathrm{o,001})$, nižjo starostjo $(\mathrm{p}<$ o,oo1), boljšo prehransko varnostjo družine $(\mathrm{p}<\mathrm{o}, \mathrm{O1})$ ter višjo izobrazbo matere $(\mathrm{p}<0,05)$ in očeta $(\mathrm{p}<0,05)$. Samoocenjen ekonomski status družine in struktura družine s povprečno oceno nista bila povezana. Prav tako z njo niso bili povezani vzgojni stili. Na drugi strani so imeli višjo povprečno oceno mladi, ki so jim starši nudili najvišjo podporo in izvajali najnižji pritisk, ob čemer je bila starševska podpora močnejši dejavnik šolske uspešnosti kot starševski pritisk. Rezultati tako potrjujejo, da je ob upoštevanju različnih družinskih dejavnikov za šolsko uspešnost mladih ključna starševska vpletenost, predvsem starševska podpora. 


\section{Razprava in sklep}

Namen pričujoče raziskave je bil preučiti vlogo starševskih kazalnikov pri šolski uspešnosti mladih. Rezultati bivariatnih analiz so pokazali, da imata oba starševska kazalnika (vzgojni stili in starševska vpletenost), kadar sta preučena posamezno, pomembno vlogo pri pojasnjevanju šolske uspešnosti mladih. Šolska uspešnost mladih se statistično značilno razlikuje glede na prevladujoči starševski vzgojni stil, pri čemer najvišjo povprečno oceno dosegajo avtoritativno vzgojeni, najnižjo pa mladi, ki so bili deležni zanemarjajoče vzgoje. To je skladno tudi z nekaterimi preteklimi raziskavami, tako med mladimi v drugih državah (gl. npr. Dornbusch et al., 1987; Newman et al., 2015; Pong et al., 2010) kot v Sloveniji (gl. npr. Cupar, 2018; Flere in Tavčar Krajnc, 2011). Pri starševski vpletenosti v izobraževanje mladostnikov pa je pomemben predvsem način vključevanja staršev - medtem ko je starševska podpora povezana $\mathrm{z}$ višjo oceno, je starševski nadzor povezan z nižjo. Slednje sicer ni povsem skladno z ugotovitvami raziskave Marjanovič Umekove in sodelavcev (2006), v kateri sta bili obe obliki starševske vpletenosti povezani $z$ nižjo oceno. Razhajanja $v$ rezultatih obeh raziskav bi sicer med drugim lahko pripisali nekaterim metodološkim razlikam, med drugim starostni strukturi vzorca in dejstvu, da smo v naši raziskavi vpletenost staršev merili s percepcijo mladostnikov, v navedeni raziskavi pa s percepcijo staršev, prav tako pa je morda v Sloveniji prišlo do sprememb glede pogostosti uporabe, predvsem pa glede učinkovitosti posameznih dimenzij starševske vpletenosti za izobraževalne dosežke mladih.

Na podlagi naših rezultatov lahko glede pomena posameznih starševskih kazalnikov sklenemo, da so za višjo šolsko uspešnost mladih v Sloveniji pomembna predvsem takšna vedenja in ravnanja staršev, ki temeljijo na toplih medsebojnih odnosih in pri katerih mladostniki vlogo staršev dojemajo kot podporno, ne pa kot (pretirano) nadzirajočo. Stimulativno vlogo topline in podpore staršev in destimulativno vlogo nadzora za pozitivne izide mladih $\mathrm{v}$ različnih državah ugotavljajo tudi nekatere druge novejše raziskave (npr. Calafat et al., 2014; Garcia et al., 2019).

Nadalje na podlagi hkratne analize različnih dejavnikov družinskega okolja ugotavljamo, da so za šolsko uspešnost mladih v Sloveniji bolj kot njihovi vzgojni stili pomembna vedenja staršev, ki se nanašajo na šolo in izobraževanje mladostnika. Podobno (manjšo) pomembnost vzgojnih stilov v primerjavi z vpletenostjo staršev pri šolski uspešnosti je nakazala tudi ena izmed meta analiz (Pinquart, 2016), vendar velja ob tem upoštevati, da je učinek vzgoje lahko tudi posreden. Vzgojni stili namreč lahko delujejo kot 
dejavnik različnih vidikov odnosa mladostnikov do izobraževanja in angažiranosti za šolsko delo, kot npr. motiviranost in zanimanje za šolo, splošna oz. akademska samopodoba in spoprijemanje z zahtevami in izzivi izobraževanja (Aunola et al., 20oo; Strage in Swanson Brandt, 1999), kar lahko prispeva k sami šolski uspešnosti. Takšno vlogo vzgojnih stilov potrjuje tudi raziskava Steinberga in sodelavcev (1992: 1266), ki so ugotovili, da je učinek vpletenosti staršev boljši, če se pojavlja v kontekstu avtoritativnega družinskega okolja. Prav zaradi tesne povezanosti družinskega in šolskega okolja bi bilo potrebno v prihodnjih raziskavah $\mathrm{v}$ analize vključiti tudi vlogo šolskega okolja. Prav tako bi bilo smiselno preučiti vlogo obeh starševskih kazalnikov pri drugih šolskih oz. izobraževalnih izidih ter analizirati morebitne mediacijske mehanizme, ki bi lahko pojasnili odnos med starševskimi vedenji (vzgojnimi stili in vpletenostjo staršev) in šolsko uspešnostjo.

Kljub nekaterim omejitvam naših ugotovitev, med drugim povezanih s presečnostjo podatkov in omejenim naborom spremenljivk izobraževalnih izidov, pričujoča raziskava zapolnjuje nekatere vrzeli dosedanjih raziskav na tem področju. Če povzamemo, ugotovitve naše raziskave potrjujejo pomembno vlogo delovanja staršev pri šolski uspešnosti mladih $\mathrm{v}$ Sloveniji, predvsem starševske vpletenosti v izobraževanje. Na tej osnovi se nakazuje tudi več potencialnih priporočil za učitelje, starše in odločevalce $\mathrm{v}$ izobraževalni politiki. $\mathrm{V}$ prvi vrsti je potrebno ozaveščanje staršev in učiteljev o pomenu staršev za šolsko uspešnost mladostnikov. Pri tem ima pomembno vlogo šola kot institucija, ki lahko preko različnih programov staršem ponudi izobraževanja in poda relevantne informacije o pomenu njihove vpletenosti v mladostnikovo izobraževanje, predvsem pa predstavi ustrezne pristope, ki se v raziskavah kažejo kot učinkovitejši (npr. značilnosti avtoritativne vzgoje in načini, kako lahko starši s svojo vpletenostjo $\mathrm{v}$ šolsko delo mladostnikov delujejo podporno). Ob tem je pomembno tudi spodbujanje sodelovanja staršev in učiteljev oz. šole pri šolskem delu otrok, ki naj bo usmerjeno predvsem v takšne aktivnosti, ki staršem omogočajo podporno vključevanje $\mathrm{v}$ šolske aktivnosti, kot je npr. dobra komunikacija med starši in učitelji. Kvalitetna medosebna interakcija med mladostniki, starši in učitelji bo imela pozitivne posledice ne zgolj za šolsko uspešnost mladostnikov, temveč bo krepila tudi druge vidike želenih izidov, vključno $\mathrm{z}$ zdravjem in dobrim počutjem vseh treh skupin akterjev. 


\section{Literatura}

Abar, Beau, Kermit L. Carter, in Adam Winsler. 2009. “The Effects of Maternal Parenting Style and Religious Commitment on Self-Regulation, Academic Achievement, and Risk Behavior among African-American Parochial College Students." Journal of Adolescence 32 (2): 259-73.

Amado, Diana, David Sánchez-Oliva, Inmaculada González-Ponce, Juan José Pulido-González, in Pedro Antonio Sánchez-Miguel. 2015. "Incidence of Parental Support and Pressure on Their Children's Motivational Processes Towards Sport Practice Regarding Gender.” PloS one 10 (6): e0128015.

Amato, Paul. 2001. "Children of Divorce in the 1990s: An Update of the Amato and Keith (1991) Metaanalysis.” Journal of Family Psychology, 15 (3): 355370 .

Anderson, Jennifer C., Jeanne B. Funk, Robert Elliott, in Peg Hull Smith. 2003. "Parental Support and Pressure and Children's Extracurricular Activities: Relationships with Amount of Involvement and Affective Experience of Participation.” Journal of Applied Developmental Psychology 24 (2): 241-57.

Aunola, Kaisa, Stattin Hakan, in Jari-Erik Nurmi. 200o. "Parenting Styles and Adolescents' Achievement Strategies.” Journal of Adolescence 23: 205-22.

Baumrind, Diana. 1970. "Socialization and Instrumental Competence in Young Children.” Young Children, 26 (2): 104-119.

Baumrind, Diana, Robert E. Larzelere, in Elizabeth B. Owens. 2010. "Effects of Preschool Parents' Power Assertive Patterns and Practices on Adolescent Development." Parenting 10 (3): 157-201.

Boonk, Lisa, Hieronymus J.M. Gijselaers, Henk Ritzen, in Saskia Brand-Gruwel. 2018. "A Review of the Relationship between Parental Involvement Indicators and Academic Achievement." Educational Research Review 24: 10-30.

Bronfenbrenner, Urie. 1979. The Ecology of Human Development: Experiments by Nature and Design. Cambridge, MA: Harvard University Press.

Calafat, Amador, Fernando García, Montse Juan, Elisardo Becoña, in José Ramón Fernández-Hermida. 2014. "Which Parenting Style Is More Protective Against Adolescent Substance Use? Evidence Within the European Context." Drug and alcohol dependence 138:185-92.

Campbell, James Reed. 1996. “Developing Cross-National Instruments: Using Cross-National Methods and Procedures.” International Journal of Educational Research 25 (6): 485-96. 
Castro, María, Eva Expósito-Casas, Esther López-Martín, Luis Lizasoain, Enrique Navarro-Asencio, in José Luis Gaviria. 2015. "Parental Involvement on Student Academic Achievement: A Meta-Analysis.” Educational Research Review 14:33-46.

Chao, Ruth K. 1994. "Beyond Parental Control and Authoritarian Parenting Style: Understanding Chinese Parenting Through the Cultural Notion of Training." Child Development 65 (4): 1111.

Cupar, Tina. 2018. "Vloga vzgojnih stilov pri šolskih izidih mladih." Šolsko svetovalno delo: revija za svetovalne delavce $v$ vrtcih, šolah in domovih 22 (2): $37-45$.

Cupar, Tina, in Danijela Lahe. 2019. "Education." In Slovenska mladina 2018/2019, urednik Andrej Naterer, 43-48. Zagreb: Friedrich Ebert Stiftung.

Darling, Nancy, in Laurence Steinberg. 1993. "Parenting Style as Context: An Integrative Model.” Psychological Bulletin 113 (3): 487-496.

Deb, Sibnath, Esben Strodl, in Jiandong Sun. 2015. “Academic Stress, Parental Pressure, Anxiety in Mental Health Among Indian High School Students." International Journal of Psychology and Behavioral Sciences 5 (1): 26-34.

Dornbusch, Sanford M., Philip L. Ritter, P. Herbert Leiderman, Donald F. Roberts, in Michael J. Fraleigh. 1987. "The Relation of Parenting Style to Adolescent School Performance.” Child Development 58 (5): 1244-57.

Fan, Xitao in Michael Chen. "Parental Involvement and Students' Academic Achievement: A Meta-analysis.” Educational psychology review 13, 1 (2001): 1-22.

Flere, Sergej, Rudi Klanjšek, Bojan Musil, Marina Tavčar Krajnc, in Andrej Kirbiš. 2009. “Kdo je uspešen v slovenski šoli?” Ljubljana: Pedagoški inštitut.

Flere, Sergej, in Marina Tavčar Krajnc. 2011. "Izobraževanje in usposabljanje.” V Mladina 2010: Družbeni profil mladih v Sloveniji, urednik Miran Lavrič, 93-124. Ljubljana; Maribor: Ministrstvo za šolstvo in šport, Urad RS za mladino; Aristej.

Garcia, Fernando, Emilia Serra, Oscar F. Garcia, Isabel Martinez, in Edie Cruise. 2019. "A Third Emerging Stage for the Current Digital Society? Optimal Parenting Styles in Spain, the United States, Germany, and Brazil." International Journal of Environmental Research and Public Health 16 (13).

Gorard, Stephen in Emma Smith. (2004). "An International Comparison of Equity in Education Systems.” Comparitive Education 40 (1): 15-28. 
Hill, Nancy E., in Diana F. Tyson. 2009. "Parental Involvement in Middle School: A Meta-Analytic Assessment of the Strategies That Promote Achievement." Developmental psychology 45 (3): 740-63.

Hoferichter, Frances, in Diana Raufelder. 2019. "Mothers and Fathers-Who Matters for STEM Performance? Gender-Specific Associations Between STEM Performance, Parental Pressure, and Support During Adolescence." Frontiers in Education 4:14.

Jeynes, William H. "Effects of Parental Involvement and Family Structure on the Academic Achievement of Adolescents." Marriage \& Family Review 37, 3 (2005): 99-116

Karbach, Julia, Juliana Gottschling, Marion Spengler, Katrin Hegewald, in Frank M. Spinath. 2013. "Parental Involvement and General Cognitive Ability as Predictors of Domain-Specific Academic Achievement in Early Adolescence." Learning and Instruction 23:43-51.

Kenney, Shannon R., Andrew Lac, Justin F. Hummer, Elizabeth M. Grimaldi, in Joseph W. LaBrie. 2015. "Pathways of Parenting Style on Adolescents' College Adjustment, Academic Achievement, and Alcohol Risk." Journal of College Student Retention: Research, Theory \& Practice 17 (2): 186-203.

Kirbiš, Andrej, Tina Cupar, in Marina Tavčar-Kranjc. 2021. "Kulturni kapital, vzgoja in razvojni izidi mladih v meddržavni primerjalni perspektivi: analiza desetih držav Jugovzhodne Evrope.” V Kulturna participacija mladih v Sloveniji in Evropi, urednik Andrej Kirbiš, 179-206. Maribor: Kulturni center, 2021.

Leff, Stephen S., in Rick H. Hoyle. 1995. "Young Athletes' Perceptions of Parental Support and Pressure." Journal of Youth Adolescence 24 (2): 187-203.

Maccoby, Eleanor, in Martin, J. A. 1983. "Socialization and the Context of the Family: Parent-Child Interaction." V Handbook of Child Psychology, urednik P. H. Mussen and E. Hetherington, 1-101. New York: Wiley.

Maccoby, Eleanor E. 200o. "Parenting and Its Effects on Children: On Reading and Misreading Behavior Genetics.” Annual Review of Psychology 51: 1-27.

Marjanovič Umek, Ljubica, Gregor Sočan, in Katja Grgić. 20o6. "Šolska ocena: Koliko jo lahko pojasnimo z individualnimi značilnostmi mladostnika in koliko z dejavniki družinskega okolja.” Psihološka obzorja 4 (15): 25-52.

Masud, Hamid, Ramayah Thurasamy, Muhammad Shakil Ahmad, H Masud, M S Ahmad, in R Thurasamy. 2015. "Parenting Styles and Academic Achievement of Young Adolescents: A Systematic Literature Review.” Quality \& Quantity 49: 2411-33. 
Newman, Joan, Hamide Gozu, Shuyi Guan, Ji Eun Lee, Xian Li, in Yuriko Sasaki. 2015. "Relationship between Maternal Parenting Style and High School Achievement and Self-Esteem in China, Turkey and U.S.A.” Journal of Comparative Family Studies 46 (2): 265-88.

Núñez, José C., Bibiana Regueiro, Natalia Suárez, Isabel Piñeiro, María Luisa Rodicio, in Antonio Valle. 2019. "Student Perception of Teacher and Parent Involvement in Homework and Student Engagement: The Mediating Role of Motivation." Frontiers in psychology 10:1384.

OECD. 2012. "Pisa 2012 Results: Redy to Learn (Students' Engagement, Drive and Self-Beliefs).” Vol. 3.

Pavić, Željko. 2016. “Cultural Capital and Educational Outcomes in Croatia: A Contextual Approach.” Sociológia 48: 572-600.

Peček, Mojca, Čuk, Ivan, in Lesar, Irena. (2006). Šola in ohranjanje družbene razslojenosti - učni uspeh in vpis osnovnošolcev na srednje šole glede na izobrazbo staršev. Sodobna pedagogika 57 (1), 10-34.

Pinquart, Martin. 2016. "Associations of Parenting Styles and Dimensions with Academic Achievement in Children and Adolescents: A Meta-Analysis." Educational Psychological Review 28 (3): 475-93.

Pinquart, Martin, in Rubina Kauser. 2018. "Do the Associations of Parenting Styles With Behavior Problems and Academic Achievement Vary by Culture? Results From a Meta-Analysis." Cultural Diversity and Ethnic Minority Psychology 24 (1): 75-100.

Pong, Suet-ling, Jamie Johnston, and Vivien Chen. 2010. "Authoritarian Parenting and Asian Adolescent School Performance: Insights from the US and Taiwan.” International Journal of Behavioral Development 34 (1): 62-72.

Radziszewska, Barbara, Jean L. Richardson, Clyde W. Dent, in Brian R. Flay. 1996. "Parenting Style and Adolescent Depressive Symptoms, Smoking, and Academic Achievement: Ethnic, Gender, and SES Differences." Journal of Behavioral Medicine 19 (3): 289-305.

Raufelder, Diana, Frances Hoferichter, Tobias Ringeisen, Nicola Regner, in Christina Jacke. 2015. "The Perceived Role of Parental Support and Pressure in the Interplay of Test Anxiety and School Engagement Among Adolescents: Evidence for Gender-Specific Relations." Journal of Child and Family Studies 24 (12): 3742-56.

Ringeisen, Tobias, in Diana Raufelder. 2015. “The Interplay of Parental Support, Parental Pressure and Test Anxiety--Gender Differences in Adolescents.” Journal of adolescence 45:67-79. 
Robinson, Clyde C., Barbara Mandleco, Susanne Frost Olsen, in Craig H. Hart. 1995. "Authoritative, Authoritarian, and Permissive Parenting Practices: Development of a New Measure.” Psychological Reports 77 (3): 819-30.

Rodgers, Kathleen Boyce in Hilary A. Rose. "Personal, Family, and School Factors Related to Adolescent Academic Performance: A Comparison by Family Structure.” Marriage \& Family Review 33, 4 (2001): 47-61.

Rohner, Ronald P. 2008. "Parental Acceptance-Rejection/Control Questionnaire (PARQ/Control).” V Handbook for the Study of Parental Acceptance and Rejection, urednika Ronald P. Rohner and Abdul Khaleque, 137-86. Storrs, Connecticut: Rohner Research.

Rohner Ronald P., Emeline O. Granum, in José M. Saavedra. 1978. “Development and Validation of the Parental Acceptance-Rejection Questionnaire: Test Manual." JSAS catalogue of selected documents in psychology 8: 7-8.

Rohner, Ronald P., in Abdul Khaleque. 2003. "Reliability and Validity of the Parental Control Scale.” Journal of Cross-Cultural Psychology 34 (6): 64349.

Steinberg, Laurence. 2001. "We Know Some Things: Parent-Adolescent Relationships in Retrospect and Prospect." Journal of Research on Adolescence 11 (1): 1-19.

Steinberg, Laurence, Julie D. Elmen, in Nina S. Mounts. 1989. "Authoritative Parenting, Psychosocial Maturity, and Academic Success among Adolescents." Child Development 6o (6): 1424-36.

Steinberg, Laurence, Susie D. Lamborn, Sanford M. Dornbusch, in Nancy Darling. 1992. "Impact of Parenting Practices on Adolescent Achievement: Authoritative Parenting, School Involvement, and Encouragement to Succeed." Child Development 63 (5): 1266-81.

Strage, Amy, in Tamara Swanson Brandt. 1999. "Authoritative Parenting and College Students' Academic Adjustment and Success.” Journal of Educational Psychology 91 (1): 146-56.

Taylor, Lorraine C., Ivora D. Hinton, in Melvin N. Wilson. 1995. "Parental Influences on Academic Performance in African-American Students." Journal of Child and Family Studies 4: 293-302.

Ule, Mirjana. 2015. "Vloga staršev v izobraževalnih potekih otrok v Sloveniji (Slovenian).” Journal of Contemporary Educational Studies / Sodobna Pedagogika 66 (1): 30.

Yasmin, Samina, Almas Kiani, in Abid Ghafoor Chaudry. 2014. "Parenting Styles as Predictors of Academic Achievement." International Journal of Technical Research and Applications 2 (6): 28-31. 